\title{
Sinergisme Serbuk Daun Ageratum conyzoides, Rimpang Curcuma longa, dan Zingiber officinale terhadap Sitophilus oryzae $\mathbf{L}$. \\ (Synergism of Leaf Powder Ageratum conyzoides, Rhizome Curcuma longa, and Zingiber officinale against Sitophilus oryzae $\mathbf{L}$.)
}

\author{
Hendrival $^{1}$, Mentari Setia Ninggsih ${ }^{1}$, Maryati $^{1}$, Cut Nura'la Putri ${ }^{1}$, Nasrianti $^{1}$ \\ ${ }^{1}$ Program Studi Agroekoteknologi, Fakultas Pertanian, Universitas Malikussaleh, Jalan Banda Aceh-Medan, Kampus Utama \\ Reuleut, Kecamatan Muara Batu, Kabupaten Aceh Utara Kode Pos 24355 email: hendrival@unimal.ac.id
}

Diterima 21 Desember 2016/Disetujui 14 Januari 2017

\begin{abstract}
Sitophilus oryzae are one of the most serious stored grain pests in the worldwide. Control by using synthetic insecticides with fumigation on can cause to $S$. oryzae resistance. One way of control that can be applied is to use a botanical insecticide. The research aimed to determine the synergism of $A$. conyzoides leaf powder, rhizome Curcuma longa and Z. officinale against imago $S$. oryzae. The research methods included single and mixed toxicity testing. Application leaf powders A. conyzoides, rhizome $C$. longa, and $Z$. officinale separately as well as an effective mixture of $S$. oryzae. Application A. conyzoides leaf powder single have LC50 value $3.96 \mathrm{mg} / \mathrm{g}$ and LC90 $15.43 \mathrm{mg} / \mathrm{g}$, Z. officinale rhizome has a value LC50 $6.29 \mathrm{mg} / \mathrm{g}$ and LC90 $15.43 \mathrm{mg} / \mathrm{g}$, and rhizome powder C. longa has LC50 value $5.27 \mathrm{mg} / \mathrm{g}$ and $31.49 \mathrm{mg} / \mathrm{g}$. The mixture leaf $A$. conyzoides with Z. officinale rhizome powder has an LC50 value of $2.47 \mathrm{mg} / \mathrm{g}$ and LC90 of $6.86 \mathrm{mg} / \mathrm{g}$, whereas the mixture with powder $C$. longa has LC50 $2.75 \mathrm{mg} / \mathrm{g}$ and $12.85 \mathrm{mg} / \mathrm{g}$. The mixture of leaf powder A. conyzoides with rhizome C. longa and Z. officinale is more toxic than its single and synergistic to imago $S$. oryzae. The mixture A. conyzoides leaf powder with $Z$. officinale rhizome powder is more toxic and synergic than its mixture with rhizome powder C. longa. Application leaf powder A. conyzoides, rhizome powder $C$. longa and $Z$. officinale on single and mixture can be used to control $S$. oryzae pests in grain during storage
\end{abstract}

Keywords: Sitophilus oryzae, Ageratum conyzoides, Curcuma longa, Zingiber officinale, synergism insecticide

\begin{abstract}
ABSTRAK
Sitophilus oryzae merupakan salah satu hama utama pada biji-bijian di penyimpanan di seluruh dunia. Pengendalian dengan menggunakan insektisida sintetik dengan fumigasi secara terus-menerus dapat mengakibatkan resistensi $S$. oryzae. Salah satu cara pengendalian yang dapat diterapkan adalah dengan menggunakan insektisida nabati. Penelitian bertujuan untuk menentukan sinergisme serbuk daun A. conyzoides, serbuk rimpang C. longa, dan Z. officinale terhadap imago S. oryzae. Metode penelitian meliputi pengujian toksisitas tunggal dan campuran. Aplikasi serbuk daun A. conyzoides, serbuk rimpang C. longa, dan Z. officinale secara terpisah maupun campuran efektif terhadap S. oryzae. Aplikasi serbuk daun A. conyzoides secara tunggal memiliki nilai LC50 3.96 mg/g dan LC90 $15.43 \mathrm{mg} / \mathrm{g}$, serbuk rimpang Z. officinale memiliki nilai LC50 6.29 $\mathrm{mg} / \mathrm{g}$ dan LC90 $15.43 \mathrm{mg} / \mathrm{g}$, dan serbuk rimpang C. longa memiliki nilai LC50 $5.27 \mathrm{mg} / \mathrm{g}$ dan $31.49 \mathrm{mg} / \mathrm{g}$. Campuran serbuk daun A. conyzoides dengan serbuk rimpang Z. officinale memiliki nilai LC50 2.478 mg/g dan LC90 $6.863 \mathrm{mg} / \mathrm{g}$, sedangkan campuran dengan serbuk rimpang $C$. longa memiliki nilai LC50 $2.757 \mathrm{mg} / \mathrm{g}$ dan $12.854 \mathrm{mg} / \mathrm{g}$. Campuran serbuk daun $A$. conyzoides dengan serbuk rimpang $C$. longa dan Z. officinale lebih beracun daripada tunggalnya dan bersifat sinergis terhadap imago $S$. oryzae. Campuran serbuk daun A. conyzoides dengan serbuk rimpang $Z$. officinale lebih beracun dan bersinergis dibandingkan campurannya dengan serbuk rimpang $C$. longa. Aplikasi serbuk daun A. conyzoides, serbuk rimpang $C$. longa dan Z. officinale secara tunggal dan campurannya dapat digunakan untuk mengendalikan hama $S$. oryzae pada gabah selama penyimpanan
\end{abstract}

Kata kunci: Sitophilus oryzae, Ageratum conyzoides, Curcuma longa, Zingiber officinale, sinergisme insektisida

\section{PENDAHULUAN}

Sitophilus oryzae menyebabkan kerugian besar pada bahan pangan selama penyimpanan secara kuantitatif maupun kualitatif di seluruh dunia. Serangga dewasa dan larva $S$. oryzae merusak bahan pangan dengan memakan karbohidrat dalam butiran biji sehingga terjadi penurunan susut berat pangan dan kontaminasi produk (Park et al., 2003), mengurangi viabilitas benih, menurunkan nilai pasar, dan mengurangi nilai gizi. Hama $S$. oryzae menyebabkan kerusakan pada biji-bijian yang disimpan pada $25-30{ }^{\circ} \mathrm{C}$ dan $\mathrm{RH}$ rendah (Batta, 2004). Untuk mengatasi permasalahan kerusakan pada bahan pangan seperti biji-biji di penyimpanan perlu dilakukan pengendalian hama $S$. oryzae, 
cara yang banyak digunakan adalah menggunakan insektisida sintetik. Pengendalian hama S. oryzae dengan insektisida sintetik banyak dilakukan secara fumigasi menggunakan insektisida fosfin atau fumigan kimia lainnya. Penggunaan insektisida sintetik dengan fumigasi secara terus-menerus dapat mengakibatkan berbagai dampak negatif seperti toksisitas pada konsumen dan resistensi $S$. oryzae (Benhalima et al., 2004). Salah satu alternatif pengendalian hama $S$. oryzae yang layak dikembangkan adalah penggunaan insektisida nabati. Penggunaan insektisida nabati sangat dianjurkan untuk mengendalikan $S$. oryzae dan hama pascapanen lainnya di penyimpanan gabah pada tingkat petani karena ketersediaan sumber insektisida nabati banyak di lingkungan petani.

Penggunaan insektisida nabati dari dapat mengurangi kerusakan biji-bijian akibat serangan $S$. oryzae selama penyimpanan merupakan salah satu cara pengendalian yang berwawasan lingkungan. Berbagai famili tumbuhan yang berpotensi sebagai sumber insektisida nabati yaitu Meliaceae, Annonaceae, Piperaceae, Verbenaceae, Asteraceae, dan Zingiberaceae. Tumbuhan Ageratum conyzoides (Asteraceae) tergolong tumbuhan liar dengan ketersediaan berlimpah dan belum banyak dimanfaatkan (Hendrival \& Marwan, 2016). Tumbuhan A. conyzoides diketahui memiliki aktivitas insektisida terhadap hama yang menyerang bahan pangan biji-bijian seperti $S$. oryzae di penyimpanan (Bouda et al., 2001; Moreira et al., 2007; Gani, 2010). Tanaman dari Zingiberaceae seperti Curcuma longa sin Curcuma domestica (Chayengia et al., 2010; Asawalam et al., 2012) dan jahe (Zingiber officinale) (Franz et al., 2011; Asawalam et al., 2012) diketahui memiliki aktivitas insektisida terhadap hama $S$. oryzae di penyimpanan. Serbuk rimpang kunyit dan jahe dapat menyebabkan kematian imago $S$. oryzae (Govindan \& Nelson, 2009). Insektisida nabati dapat digunakan secara tunggal atau campuran, namun sebelum insektisida digunakan dalam bentuk campuran, sifat aktivitasnya perlu diketahui. Pengujian serbuk daun A. conyzoides, serbuk rimpang $C$. longa, dan $Z$. officinale perlu dilakukan untuk mengevaluasi aktivitas insektisida terhadap $S$. oryzae. Penelitian bertujuan untuk menentukan sinergisme serbuk daun A. conyzoides, serbuk rimpang C. longa, dan $Z$. officinale terhadap imago S. oryzae.

\section{BAHAN DAN METODE}

Penelitian dilaksanakan di Laboratorium Hama dan Penyakit Tanaman, Program Studi Agroekoteknologi, Fakultas Pertanian Universitas Malikussaleh dari bulan Agustus 2015 sampai Desember 2016. Pembiakkan serangga $S$. oryzae dilakukan pada stoples dengan kapasitas $0,5 \mathrm{~kg}$ yang berisikan beras merah sebanyak $250 \mathrm{~g}$. Imago $S$. oryzae yang diperoleh dari gudang penyimpanan padi diinfestasikan ke dalam stoples pemeliharaan dengan tingkat populasi 50 pasang imago $S$. oryzae dengan $250 \mathrm{~g}$ beras merah. Pembiakan $S$. oryzae dilakukan selama empat minggu sesuai dengan siklus hidup $S$. oryzae dari peletakkan telur hingga keluarnya imago. Pengayakan beras dilakukan untuk memisahkan 50 pasang imago $S$. oryzae dari media beras, setelah masa infestasi selesai dilakukan. Media beras tersebut diinkubasikan kembali sampai muncul imago $S$. oryzae yang baru. Imago-imago $S$. oryzae tersebut disimpan pada media beras yang baru. Pengayakan dilakukan secara berulang setiap hari hingga didapatkan jumlah imago $S$. oryzae dengan umur yang seragam.

Pembuatan insektisida nabati dengan cara memotong bahan nabati segar dari daun $A$. conyzoides serta rimpang $C$. longa dan $Z$. officinale menjadi ukuran tipis $(0,5-1 \mathrm{~mm})$. Bahan nabati dari daun $A$. conyzoides dikeringanginkan selama 48 jam, sedangkan dari rimpang $C$. longa dan $Z$. officinale dikeringanginkan selama 5 hari, setelah bahan nabati tersebut kering, kemudian dihancurkan dengan menggunakan blender sampai menjadi serbuk. Serbuk dari hasil penghancuran kemudian disaring dengan menggunakan ayakan yang berlapiskan kain organdi untuk mendapatkan serbuk yang lebih halus dan digunakan sebagai bahan insektisida nabati untuk penelitian.

\section{Pengujian Toksisitas Tunggal}

Pengujian toksisitas insektisida nabati menggunakan konsentrasi serbuk insektisida nabati yaitu 2.5, 5, 10, 20, 40, 80 , dan $160 \mathrm{mg} / \mathrm{g}$ gabah serta kontrol. Untuk setiap taraf konsentrasi menggunakan 60 ekor imago $S$. oryzae dengan tiga ulangan (20 ekor imago $S$. oryzae per ulangan). Aplikasi bahan insektisida menggunakan metode pencampuran dengan makanan. Cara ini biasanya terbatas untuk biji-bijian yang digunakan sebagai benih, bukan untuk konsumsi (Hendrival \& Marwan, 2016). Pengujian bahan insektisida nabati terhadap $S$. oryzae dilakukan mencampurkan bahan insektisida dengan gabah padi dari varietas Ciherang sebanyak $100 \mathrm{~g}$ gabah per stoples plastik. Campuran bahan insektisida nabati dan padi ditempatkan ke dalam stoples plastik dengan ukuran diameter $5 \mathrm{~cm}$ dan 10 $\mathrm{cm}$. Imago $S$. oryzae yang berumur 7-14 hari dari hasil pembiakan dengan tingkat populasi 10 pasang imago dimasukkan ke dalam stoples plastik dan disimpan selama pelaksanaan penelitian. Mortalitas imago $S$. oryzae mulai dicatat sejak 1 sampai 10 hari setelah aplikasi (HSA) bahan insektisida nabati. Hubungan kematian serangga uji dengan konsentrasi bahan insektisida nabati dapat digambarkan dalam hubungan probit. Nilai LC50 dan LC90 dihitung dengan analisis probit menggunakan program POLO-PLUS.

\section{Pengujian Toksisitas Campuran}

Serbuk daun A. conyzoides, serbuk rimpang C. longa, dan $Z$. officinale diuji dalam bentuk campuran pada tujuh taraf konsentrasi yang diharapkan dapat mengakibatkan kematian imago S. oryzae antara 5 sampai 90\%. Pengujian toksisitas campuran serbuk daun $A$. conyzoides dengan serbuk rimpang $C$. longa dan $Z$. officinale pada perbandingan yaitu 1:2 (b/b) yang ditentukan berdasarkan hasil pengujian toksisitas secara tunggal. Konsentrasi campuran serbuk daun $A$. conyzoides dengan serbuk rimpang Z. officinale yaitu 2.07, 4.14, 8.27, 16.55, 33.09, 66.18, $132.37 \mathrm{mg} / \mathrm{g}$, dan kontrol. Konsentrasi campuran serbuk daun $A$. conyzoides dengan serbuk rimpang $C$. longa yaitu 
$1.82,3.63,7.26,14.52,29.04,58.07,116.14 \mathrm{mg} / \mathrm{g}$, dan kontrol. Untuk setiap taraf konsentrasi menggunakan 60 ekor imago $S$. oryzae dengan tiga ulangan (20 ekor imago $S$. oryzae per ulangan). Cara pengujian dan waktu pengamatan pada toksisitas campuran seperti pada pengujian toksisitas tunggal.

Sifat aktivitas campuran dianalisis berdasarkan model kerja bersama berbeda dengan menghitung indeks kombinasi pada taraf LC50 dan LC90. Indeks kombinasi tersebut dihitung dengan rumus berikut (Chou \& Talalay, 1984) yaitu.

$\mathrm{IK}=\frac{\mathrm{LC}_{\mathrm{x}}^{1 \text { (campuran) }}}{\mathrm{LC}_{\mathrm{x}}^{1}}+\frac{\mathrm{LC}_{\mathrm{x}}^{2 \text { (campuran) }}}{\mathrm{LC}_{\mathrm{x}}^{2}}+\left[\frac{\mathrm{Lc}_{\mathrm{x}}^{1 \text { (campuran) }}}{\mathrm{LC}_{\mathrm{x}}^{1}} \times \frac{\mathrm{LC}_{\mathrm{x}}^{2 \text { (campuran) }}}{\mathrm{LC}^{2} \mathrm{CC}_{\mathrm{x}}^{2}}\right]$ serbuk daun A. conyzoides, serbuk rimpang C. longa, dan $Z$. officinale pada pengujian tunggal; $\operatorname{LC}_{\mathrm{x}}{ }^{1 \text { (campuran) }}$ dan $\mathrm{LC}_{\mathrm{x}}{ }^{2 \text { (campuran) }}$ masing-masing $\mathrm{LC}_{\mathrm{x}}$ serbuk daun $A$. conyzoides, serbuk rimpang $C$. longa, dan $Z$. officinale dalam campuran yang mengakibatkan mortalitas x (misal 50\% dan 90\%). Nilai LCx tersebut diperoleh dengan cara mengalikan

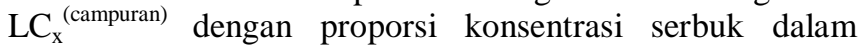
campuran. Kategori sifat interaksi campuran sebagai berikut (diadaptasi dari Gisi, 1996) yaitu sinergistik kuat (IK < 0.5), sinergistik lemah $(0.5 \leq \mathrm{IK} \leq 0.77)$, aditif $(0.77<\mathrm{IK} \leq 1.43)$, dan antagonistik (IK > 1.43).

\section{HASIL DAN PEMBAHASAN}

\section{Toksisitas Tunggal Insektisida Nabati}

Perkembangan mortalitas imago $S$. oryzae setelah aplikasi serbuk daun $A$. conyzoides, serbuk rimpang $C$. longa, dan Z. officinale menunjukkan pola yang serupa dengan mortalitas mencapai > $95 \%$ sampai akhir pengamatan. Mortalitas imago $S$. oryzae setelah aplikasi serbuk daun $A$. conyzoides, serbuk rimpang C. longa, dan $Z$. officinale banyak terjadi pada pengamatan 2-8 HSA. Peningkatan mortalitas imago $S$. oryzae terpaut dengan peningkatan konsentrasi serbuk daun A. conyzoides, serbuk rimpang $C$. longa, dan $Z$. officinale sehingga diketahui bahwa aktivitas insektisida dari serbuk-serbuk tersebut bersifat aktif secara kuantitatif. Mortalitas imago S. oryzae yang meningkat berdasarkan lamanya pengamatan menunjukkan bahwa kematian imago secara bertahap dan tidak terjadi segera setelah aplikasi serbuk daun $A$. conyzoides, serbuk rimpang $C$. longa, dan Z. officinale. Penilaian hubungan konsentrasi serbuk daun $A$. conyzoides, serbuk rimpang $C$. longa, dan $Z$. officinale terhadap mortalitas imago $S$. oryzae ditentukan dari pengamatan 4-10 HSA (Gambar 1).
A

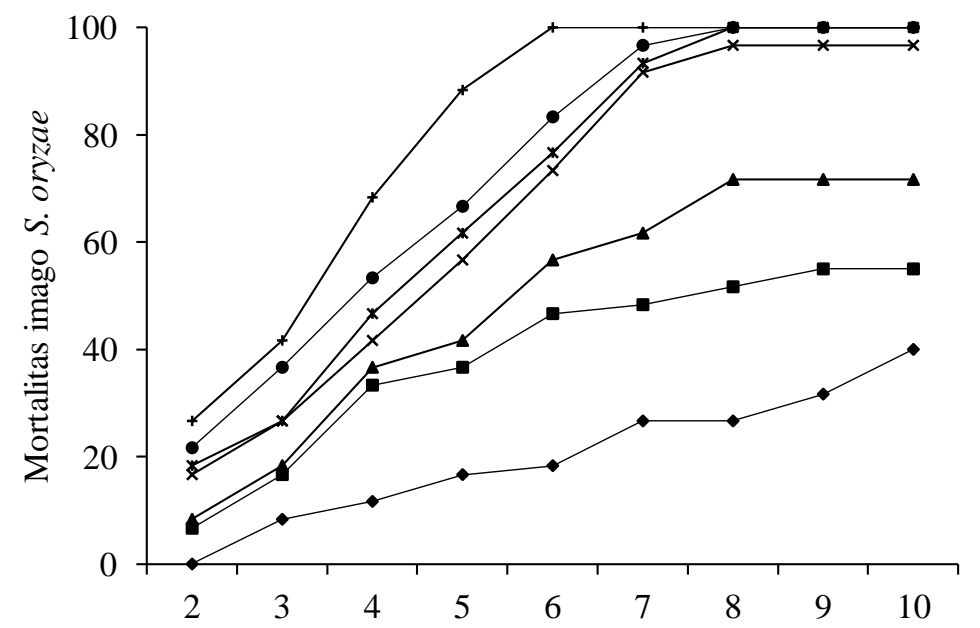

B

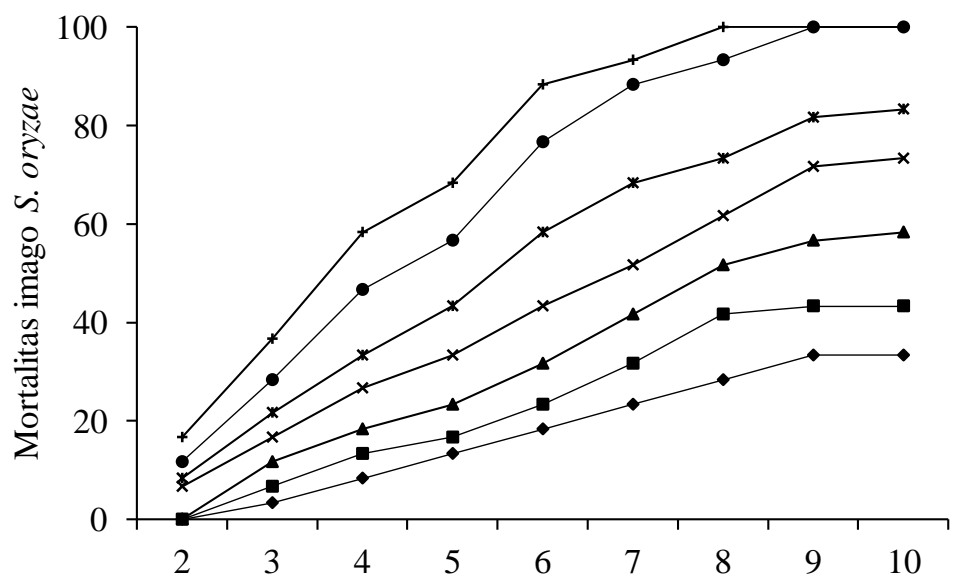

$\longrightarrow 2,5 \mathrm{mg} / \mathrm{g}$

$\rightarrow-5 \mathrm{mg} / \mathrm{g}$

$\leftarrow 10 \mathrm{mg} / \mathrm{g}$

$\longrightarrow 20 \mathrm{mg} / \mathrm{g}$

* $40 \mathrm{mg} / \mathrm{g}$

$\longrightarrow 80 \mathrm{mg} / \mathrm{g}$

— $160 \mathrm{mg} / \mathrm{g}$

$\longrightarrow 2,5 \mathrm{mg} / \mathrm{g}$

$\rightarrow-5 \mathrm{mg} / \mathrm{g}$

$\longrightarrow 10 \mathrm{mg} / \mathrm{g}$

$\leftarrow 20 \mathrm{mg} / \mathrm{g}$

* $40 \mathrm{mg} / \mathrm{g}$

$\longrightarrow 80 \mathrm{mg} / \mathrm{g}$

$\longrightarrow 160 \mathrm{mg} / \mathrm{g}$ 
$\mathbf{C}$

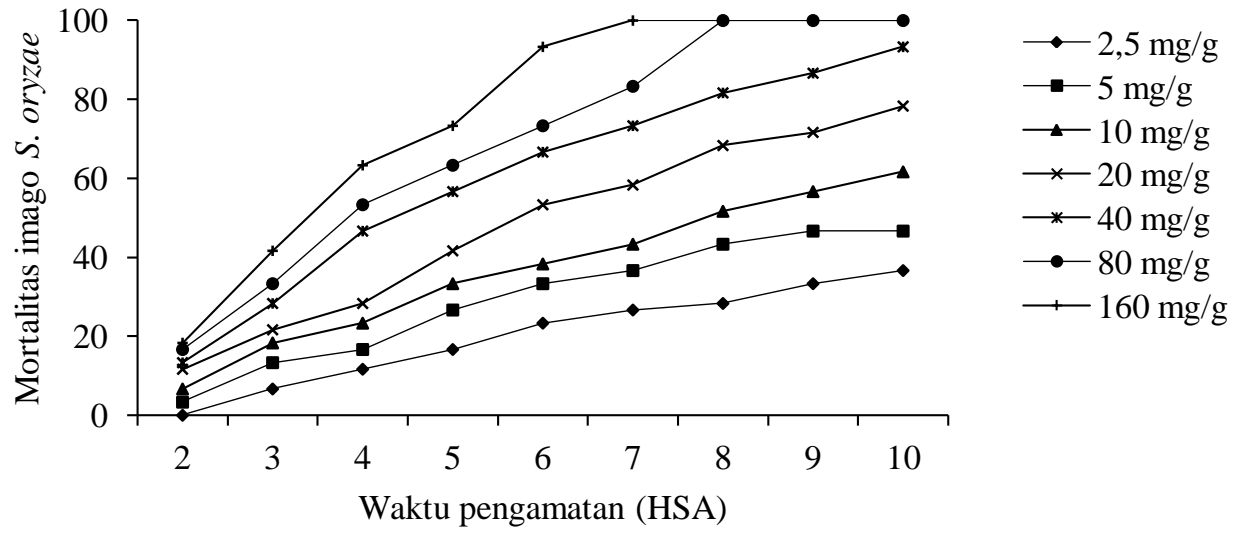

Gambar 1. Perkembangan tingkat mortalitas imago S. oryzae pada perlakuan dengan serbuk daun A. conyzoides (A), serbuk rimpang $Z$. officinale (B), dan serbuk rimpang $C$. longa $(\mathrm{C})$. Pada semua perlakuan insektisida nabati, tidak ada kematian larva kontrol hingga 10 HSA

Tabel 1. Pendugaan parameter hubungan konsentrasi insektisida nabati dengan mortalitas imago S. oryzae

\begin{tabular}{|c|c|c|c|c|c|}
\hline $\begin{array}{c}\text { Jenis insektisida } \\
\text { nabati }\end{array}$ & $\begin{array}{l}\text { Waktu } \\
\text { penilaian } \\
\text { (hari } \\
\text { setelah } \\
\text { aplikasi) }\end{array}$ & $\begin{array}{l}\text { Intersep garis } \\
\text { probit } \\
\pm \text { galat baku }\end{array}$ & $\begin{array}{l}\text { Kemiringan } \\
\text { regresi probit } \\
\pm \text { galat baku }\end{array}$ & $\begin{array}{c}\text { LC50 } \\
\text { (selang kepercayaan } \\
95 \%)(\mathrm{mg} / \mathrm{g})\end{array}$ & $\begin{array}{c}\text { LC90 } \\
\text { (selang kepercayaan } 95 \% \\
(\mathrm{mg} / \mathrm{g})\end{array}$ \\
\hline \multirow[t]{7}{*}{ A. conyzoides } & 4 & $3.845 \pm 0.160$ & $0.710 \pm 0.109$ & $42.22(27.99-72.53)$ & tidak tercapai \\
\hline & 5 & $3.811 \pm 0.160$ & $0.972 \pm 0.114$ & $16.66(12.10-22.58)$ & tidak tercapai \\
\hline & 6 & $3.803 \pm 0.242$ & $1.306 \pm 0.191$ & $8.23(4.33-13.05)$ & $78.81(42.56-255.47)$ \\
\hline & 7 & $3.653 \pm 0.188$ & $1.817 \pm 0.178$ & $5.50(4.31-6.77)$ & $27.93(21.56-39.42)$ \\
\hline & 8 & $3.256 \pm 0.237$ & $2.558 \pm 0.273$ & $4.80(3.98-5.65)$ & $15.22(12.29-20.44)$ \\
\hline & 9 & $3.460 \pm 0.229$ & $2.388 \pm 0.263$ & $4.41(3.57-5.25)$ & $15.17(12.14-20.66)$ \\
\hline & 10 & $3.702 \pm 0.218$ & $2.170 \pm 0.248$ & $3.96(3.09-4.82)$ & $15.43(12.20-21.44)$ \\
\hline \multirow[t]{7}{*}{ Z. officinale } & 4 & $3.241 \pm 0.184$ & $0.874 \pm 0.119$ & $102.34(66.83-192.37)$ & tidak tercapai \\
\hline & 5 & $3.413 \pm 0.172$ & $0.912 \pm 0.115$ & $54.66(38.68-85.78)$ & tidak tercapai \\
\hline & 6 & $3.444 \pm 0.168$ & $1.165 \pm 0.118$ & $21.59(16.64-28.20)$ & tidak tercapai \\
\hline & 7 & $3.623 \pm 0.165$ & $1.234 \pm 0.122$ & $13.03(9.97-16.68)$ & $142.32(93.80-255.66)$ \\
\hline & 8 & $3.775 \pm 0.166$ & $1.319 \pm 0.132$ & $8.47(6.38-10.82)$ & $79.43(55.26-131.46)$ \\
\hline & 9 & $3.851 \pm 0.169$ & $1.408 \pm 0.142$ & $6.53(4.87-8.33)$ & $53.12(38.29-83.22)$ \\
\hline & 10 & $3.791 \pm 0.174$ & $1.514 \pm 0.151$ & $6.29(4.77-7.92)$ & $44.17(32.55-66.89)$ \\
\hline \multirow[t]{7}{*}{ C. longa } & 4 & $3.401 \pm 0.174$ & $0.878 \pm 0.115$ & $64.47(44.48-106.83)$ & tidak tercapai \\
\hline & 5 & $3.712 \pm 0.162$ & $0.864 \pm 0.111$ & $30.35(21.68-44.48)$ & tidak tercapai \\
\hline & 6 & $3.744 \pm 0.161$ & $1.074 \pm 0.117$ & $14.74(10.96-19.46)$ & $229.74(137.39-489.74)$ \\
\hline & 7 & $3.713 \pm 0.164$ & $1.252 \pm 0.126$ & $10.64(8.06-13.63)$ & $112.23(75.39-196.13)$ \\
\hline & 8 & $3.655 \pm 0.245$ & $1.546 \pm 0.208$ & $7.40(4.40-10.99)$ & $49.92(29.96-123.35)$ \\
\hline & 9 & $3.794 \pm 0.175$ & $1.529 \pm 0.153$ & $6.13(4.65-7.72)$ & $42.21(31.20-63.69)$ \\
\hline & 10 & $3.806 \pm 0.182$ & $1.651 \pm 0.168$ & $5.27(4.01-6.60)$ & $31.49(23.77-46.11)$ \\
\hline
\end{tabular}

Hasil analisis probit menunjukkan bahwa nilai LC50 dan LC90 dari serbuk daun A. conyzoides, rimpang C. longa dan Z. officinale mengalami penurunan tajam sampai pada 8 HSA. Penurunan nilai LC50 dan LC90 tersebut karena terjadinya peningkatan jumlah imago $S$. oryzae yang mati, sedangkan pada akhir pengamatan terjadi penurunan nilai LC50 dan LC90 yang rendah karena terjadinya penurunan jumlah imago $S$. oryzae yang mati. Nilai LC50 dan LC90 dari serbuk daun $A$. conyzoides cenderung lebih rendah dibandingkan dengan serbuk rimpang $C$. longa dan $Z$. officinale (Tabel 1). Berdasarkan nilai LC50 pada pengamatan 10 HSA diketahui bahwa serbuk daun $A$. conyzoides memiliki sekitar 1.58 kali lebih beracun dari serbuk rimpang $Z$. officinale dan 1.33 kali lebih beracun dari serbuk rimpang $C$. longa, sedangkan serbuk rimpang $C$. longa memiliki sekitar 1.19 kali lebih beracun dari rimpang Z. officinale. Serbuk daun A. conyzoides memiliki toksisitas 
yang tinggi terhadap imago $S$. oryzae dibandingkan dengan serbuk rimpang $C$. longa dan Z. officinale.

\section{Toksisitas Campuran Insektisida Nabati}

Perkembangan mortalitas imago $S$. oryzae setelah aplikasi campuran serbuk daun A. conyzoides dengan serbuk rimpang $C$. longa dan $Z$. officinale menunjukkan pola yang serupa dengan mortalitas mencapai > 95\% sampai akhir pengamatan. Mortalitas imago $S$. oryzae setelah aplikasi campuran serbuk daun A. conyzoides dengan serbuk rimpang C. longa, dan $Z$. officinale banyak terjadi pada pengamatan 2-9 HSA. Peningkatan mortalitas imago $S$. oryzae terpaut dengan peningkatan konsentrasi campuran serbuk daun $A$. conyzoides dengan serbuk rimpang $C$. longa dan $Z$. officinale sehingga diketahui bahwa aktivitas insektisida dari campuran tersebut bersifat aktif secara kuantitatif (Gambar 2). Berdasarkan hasil analisis probit diketahui bahwa nilai LC50 dan LC90 campuran serbuk daun A. conyzoides dengan serbuk rimpang $Z$. officinale lebih rendah dari campuran serbuk rimpang $C$. longa (Tabel 2). Berdasarkan taraf LC50 diketahui bahwa campuran serbuk daun $A$. conyzoides dengan serbuk rimpang $Z$. officinale lebih beracun 1.59 kali dibandingkan aplikasi serbuk daun $A$. conyzoides secara tunggal dan lebih beracun 2.53 kali dibandingkan aplikasi serbuk rimpang $Z$. officinale secara tunggal, sedangkan campuran serbuk daun $A$. conyzoides dengan serbuk rimpang $C$. longa lebih beracun 1.44 dibandingkan aplikasi serbuk daun A. conyzoides secara tunggal dan lebih beracun 1.91 kali lipat aplikasi serbuk rimpang $C$. longa secara tunggal.
A

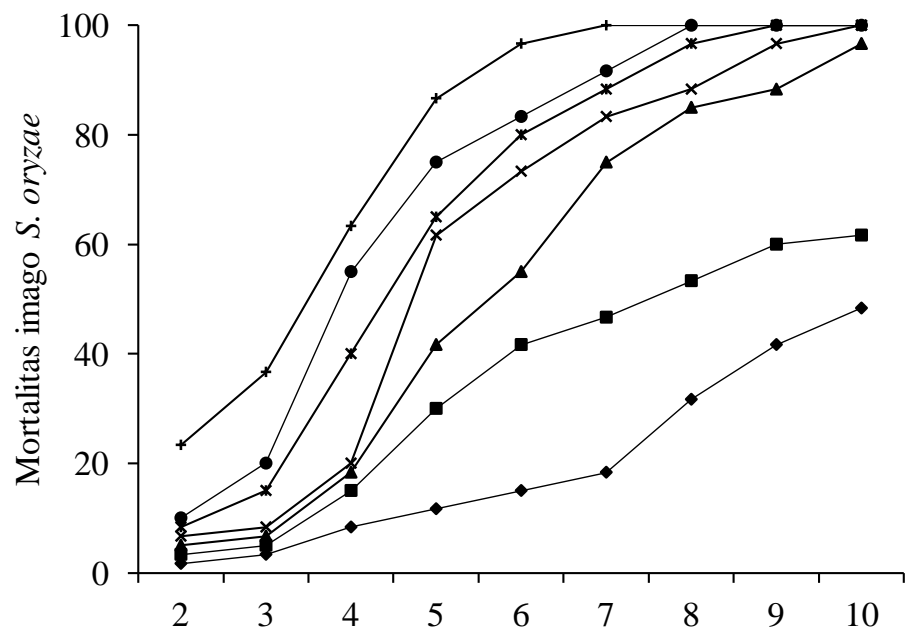

B

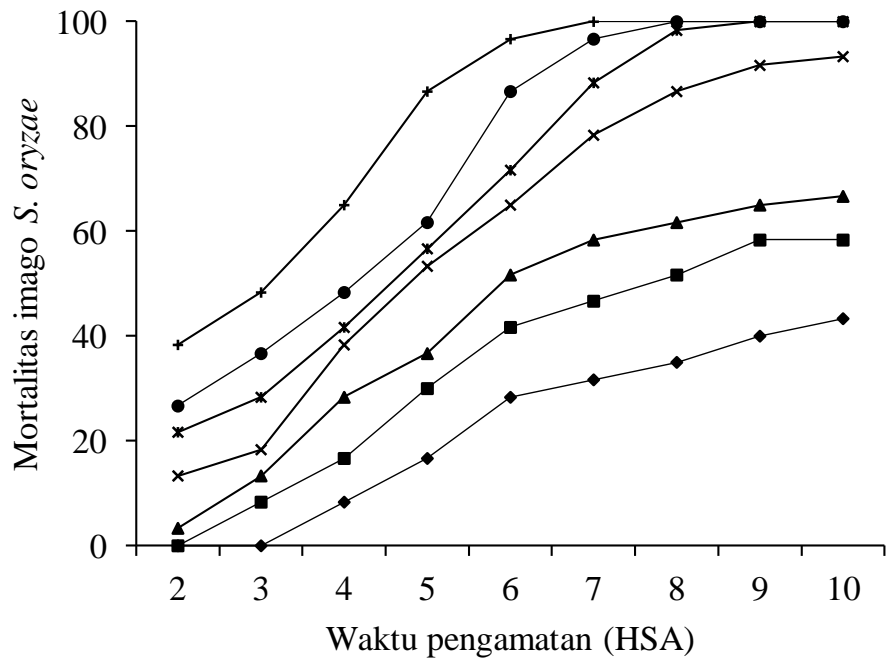

$\longrightarrow 2,07 \mathrm{mg} / \mathrm{g}$

$\longrightarrow 4,14 \mathrm{mg} / \mathrm{g}$

$-8,27 \mathrm{mg} / \mathrm{g}$

$\rightarrow 16,546 \mathrm{mg} / \mathrm{g}$

* $33,09 \mathrm{mg} / \mathrm{g}$

- $66,18 \mathrm{mg} / \mathrm{g}$

- $132,37 \mathrm{mg} / \mathrm{g}$ $\longrightarrow 1,82 \mathrm{mg} / \mathrm{g}$

$\longrightarrow 3,63 \mathrm{mg} / \mathrm{g}$

$\leftarrow 7,26 \mathrm{mg} / \mathrm{g}$

$\rightarrow 14,52 \mathrm{mg} / \mathrm{g}$

* $29,04 \mathrm{mg} / \mathrm{g}$

$\longrightarrow 58,07 \mathrm{mg} / \mathrm{g}$

$\longrightarrow 116,144 \mathrm{mg} / \mathrm{g}$

Gambar 2. Perkembangan tingkat mortalitas imago S. oryzae pada campuran serbuk daun A. conyzoides dengan serbuk rimpang Z. officinale (A) dan serbuk rimpang $C$. longa (B). Pada semua perlakuan insektisida nabati, tidak ada kematian larva kontrol hingga 10 HSA 
Berdasarkan nilai indeks kombinasi diketahui bahwa campuran serbuk daun $A$. conyzoides dengan serbuk rimpang Z. officinale pada taraf LC50 bersifat aditif pada 5 HSA, sinergistik kuat pada 5 HSA, serta sinergistik lemah pada 610 HSA, sedangkan pada taraf LC90 bersifat sinergistik lemah pada 7 HSA dan sinergistik kuat pada 8-10 HSA. Campuran serbuk daun $A$. conyzoides dengan serbuk rimpang $C$. longa pada taraf LC50 bersifat aditif pada 4 HSA dan sinergistik lemah pada 5-10 HSA, sedangkan pada taraf LC90 bersifat sinergistik lemah pada 7-10 HSA (Tabel 3). Sifat aditif menunjukkan bahwa tingkat mortalitas imago $S$. oryzae akibat perlakuan campuran serbuk daun $A$. conyzoides dengan serbuk rimpang $C$. longa dan $Z$. officinale tidak berbeda dengan mortalitas pada aplikasi secara tunggal, sedangkan sinergistik lemah menunjukkan bahwa perlakuan dengan campuran tersebut mengakibatkan mortalitas yang sedikit lebih tinggi dibandingkan dengan mortalitas pada aplikasi secara tunggal, serta sinergistik kuat menunjukkan bahwa aplikasi campuran tersebut mengakibatkan tingkat mortalitas lebih tinggi dibandingkan dengan mortalitas pada aplikasi secara tunggal.

Aplikasi serbuk daun $A$. conyzoides, serbuk rimpang C. longa dan Z. officinale dapat menyebabkan mortalitas imago $S$. oryzae. Spesies-spesies tumbuhan tersebut diketahui memiliki aktivitas insektisidal yang menyebabkan mortalitas dan menekan populasi imago $S$. oryzae. Seperti yang dikemukakan oleh Hendrival \& Marwan (2016) bahwa serbuk dari tumbuh-tumbuhan dapat digunakan untuk menekan populasi serangga hama pascapanen di gudang penyimpanan bahan pangan. Perbedaan mortalitas imago $S$. oryzae pada berbagai konsentrasi serbuk insektisida nabati dipengaruhi oleh perbedaan kandungan senyawa aktif insektisidal dari konsentrasi yang diuji. Semakin tinggi konsentrasi serbuk insektisida nabati yang digunakan semakin banyak kandungan senyawa aktif insektisidal, sehingga menyebabkan semakin tinggi mortalitas imago $S$. oryzae. Kandungan senyawa aktif insektisidal dari serbuk daun A. conyzoides menyebabkan mortalitas imago S. oryzae lebih tinggi dibandingkan dari serbuk rimpang $C$. longa dan Z. officinale.

Tumbuhan A. conyzoides diketahui memiliki senyawa kumarin yaitu surangin B (Nicholson \& Zhang, 1995). Senyawa surangi B merupakan senyawa yang kuat menghambat transportasi elektron di dalam mitokondria sehingga mengurangi produksi ATP. Senyawa surangin B memiliki potensi untuk melepaskan neurotransmitter pada syaraf pusat serangga (Nicholson \& Zhang, 1995). Zheng et al. (1998) menyatakan bahwa surangin B memiliki potensi menimbulkan gangguan fungsional dalam mitokondria otot dan sistem saraf. Tumbuhan A. conyzoides diketahui juga senyawa aktif insektisidal lainnya yaitu precocene I dan precocene II (Okunade, 2002). Precocene I dan precocene II merupakan hormon anti juvenile yang dapat menganggu proses pembentukan larva dan berlanjut pada pada pembentukan pupa dan serangga dewasa dengan mekanisme penghambatan terjadi melalui terganggunya perintah otak pada serangga (Singh \& Rao, 2000).

Rimpang dari $C$. longa diketahui memiliki kandungan senyawa insektisidal seperti ar-turmeron dan turmeron yang diisolasi dari serbuk rimpang kunyit (Damalas, 2011). Senyawa ar-turmeron dan turmeron diketahui memiliki sifat repellents atau penolakan makan pada serangga (Zhang et al., 2008; Li et al., 2010; Xiao et al., 2011) seperti Tribolium castaneum (Iqbal et al., 2010), Oryzaephilus surinamensis, Cryptolestes ferrugineus, Sitophilus oryzae, dan Corcyra cephalonica (Chander et al., 2000). Senyawa ar-turmeron sangat beracun terhadap $S$. zeamais dan Spodotera frugiperda pada dosis rendah (Tavares et al., 2013). Rimpang dari Z. officinale telah diketahui memiliki kandungan kimia yang bersifat insektisidal (Ukeh 2008, Owolabi et al., 2009). Beberapa kandungan kimia dari jahe yaitu geranial (16\%), $\alpha$ zingiberene (13\%), neral (10\%), dan $\alpha$-farnesene $(5 \%)$ (Franz et al., 2011). Senyawa-senyawa tersebut diketahui memiliki aktivitas penolakan makan pada Tribolium castaneum, S. oryzae, $R$. dominica, dan $O$. surinamensis (Shaaya et al., 1997) dan efek kematian pada Trogoderma granarium (Ahmad et al., 2013). Asawalam et al. (2012) melaporkan bahwa aplikasi serbuk rimpang kunyit dan jahe dapat menyebabkan peningkatan mortalitas imago $S$. oryzae.

Campuran serbuk daun $A$. conyzoides dengan serbuk rimpang $Z$. officinale memiliki sifat aktivitas yang dominan sama yaitu sinergistik lemah pada taraf LC50 dan lebih efektif pada taraf LC90 dibandingkan campuran serbuk daun A. conyzoides dengan serbuk rimpang C. longa. Aplikasi serbuk daun $A$. conyzoides dengan penambahan serbuk rimpang $Z$. officinale secara bersamaan dapat meningkatkan toksisitas terhadap imago $S$. oryzae daripada apliksi secara tunggal dari serbuk daun A. conyzoides dan rimpang $Z$. officinale. Aplikasi campuran serbuk daun A. conyzoides dengan serbuk rimpang $Z$. officinale dan $C$. longa dapat meningkatkan efisiensi aplikasi insektisida nabati terhadap imago $S$. oryzae karena bersifat sinergis sehingga penggunaan campurannya sangat dianjurkan sebagai protektan pada gabah atau benih padi selama penyimpanan. Penggunaan campuran insektisida nabati yang bersifat sinergistik dapat mengurangi jumlah pemakaian bahan baku dibandingkan dengan insektisida nabati yang mengandung serbuk tunggal, sehingga dapat mengatasi keterbatasan bahan baku insektisida botani di tingkat petani karena tumbuhan sumber insektisida botani tidak selalu terdapat melimpah di suatu daerah. Penggunaan campuran insektisida nabati pada dosis yang lebih rendah juga dapat mengurangi dampak samping terhadap organisme bukan sasaran dan lingkungan. Selain itu, penggunaan campuran insektisida botani yang komponennya memiliki cara kerja berbeda dapat menunda terjadinya resistensi hama. 
Tabel 2. Pendugaan parameter toksisitas campuran serbuk daun A. conyzoides dengan serbuk rimpang $C$. longa dan $Z$. officinale terhadap mortalitas imago $S$. oryzae

\begin{tabular}{lccccc}
\hline $\begin{array}{c}\text { Campuran } \\
\text { insektisida } \\
\text { nabati }\end{array}$ & $\begin{array}{c}\text { Waktu } \\
\text { penilaian } \\
\text { (hari } \\
\text { setelah } \\
\text { aplikasi) }\end{array}$ & $\begin{array}{c}\text { Intersep garis } \\
\text { probit } \\
\text { galat baku }\end{array}$ & $\begin{array}{c}\text { Kemiringan } \\
\text { regresi probit } \\
\pm \text { galat baku }\end{array}$ & $\begin{array}{c}\text { LC50 } \\
\text { (selang kepercayaan } \\
95 \%)(\mathrm{mg} / \mathrm{g})\end{array}$ & $\begin{array}{c}\text { LC90 } \\
\text { (selang kepercayaan } \\
95 \%(\mathrm{mg} / \mathrm{g})\end{array}$ \\
\hline Serbuk daun & 4 & $3.223 \pm 0.177$ & $0.991 \pm 0.121$ & $62.01(43.74-99.37)$ & tidak tercapai \\
A. & 5 & $3.687 \pm 0.157$ & $1.152 \pm 0.119$ & $13.75(10.46-17.86)$ & tidak tercapai \\
conyzoides + & 6 & $3.819 \pm 0.158$ & $1.342 \pm 0.131$ & $7.57(5.74-9.62)$ & tidak tercapai \\
serbuk & 7 & $3.871 \pm 0.251$ & $1.615 \pm 0.233$ & $4.99(2.70-7.63)$ & $31.06(18.83-76.19)$ \\
rimpang $Z$ & 8 & $3.897 \pm 0.191$ & $2.033 \pm 0.219$ & $3.48(2.70-4.27)$ & $14.87(11.70-20.60)$ \\
officinale & 9 & $3.928 \pm 0.217$ & $2.403 \pm 0.297$ & $2.78(2.16-3.38)$ & $9.52(7.64-13.02)$ \\
& 10 & $3.858 \pm 0.252$ & $2.897 \pm 0.405$ & $2.47(1.95-2.94)$ & $6.86(5.61-9.27)$ \\
\hline Serbuk daun & 4 & $3.466 \pm 0.159$ & $0.862 \pm 0.115$ & $45.95(31.58-76.67)$ & tidak tercapai \\
A. & 5 & $3.847 \pm 0.147$ & $0.962 \pm 0.113$ & $11.75(11.55-21.62)$ & tidak tercapai \\
conyzoides + & 6 & $4.083 \pm 0.145$ & $1.149 \pm 0.123$ & $6.27(4.52-8.24)$ & tidak tercapai \\
serbuk & 7 & $4.030 \pm 0.156$ & $1.532 \pm 0.153$ & $4.29(3.24-5.42)$ & $29.47(21.86-44.16)$ \\
rimpang $C$ C & 8 & $3.963 \pm 0.171$ & $1.891 \pm 0.197$ & $3.52(2.75-4.33)$ & $16.79(13.01-23.77)$ \\
longa & 9 & $4.093 \pm 0.176$ & $1.932 \pm 0.215$ & $2.94(2.24-3.64)$ & $13.56(10.54-19.21)$ \\
& 10 & $4.155 \pm 0.177$ & $1.917 \pm 0.219$ & $2.75(2.07-3.43)$ & $12.85(9.98-18.26)$ \\
\hline
\end{tabular}

Tabel 3. Sifat aktivitas campuran serbuk daun A. conyzoides dengan serbuk rimpang C. longa dan Z. officinale terhadap mortalitas imago S. oryzae

\begin{tabular}{|c|c|c|c|c|c|}
\hline \multirow{2}{*}{$\begin{array}{c}\text { Campuran } \\
\text { insektisida nabati }\end{array}$} & \multirow{2}{*}{$\begin{array}{l}\text { Waktu penilaian } \\
\text { (hari setelah } \\
\text { aplikasi) }\end{array}$} & \multicolumn{2}{|c|}{ Indeks kombinasi } & \multicolumn{2}{|c|}{ Sifat aktivitas campuran } \\
\hline & & LC50 & LC90 & LC50 & LC90 \\
\hline Serbuk daun $A$. & 4 & 1.091 & - & Aditif & - \\
\hline conyzoides + serbuk & 5 & 0.489 & - & Sinergistik kuat & - \\
\hline rimpang $Z$. & 6 & 0.612 & - & Sinergistik lemah & - \\
\hline \multirow[t]{4}{*}{ officinale } & 7 & 0.636 & 0.570 & Sinergistik lemah & Sinergistik lemah \\
\hline & 8 & 0.582 & 0.491 & Sinergistik lemah & Sinergistik kuat \\
\hline & 9 & 0.555 & 0.354 & Sinergistik lemah & Sinergistik kuat \\
\hline & 10 & 0.526 & 0.267 & Sinergistik lemah & Sinergistik kuat \\
\hline Serbuk daun $A$. & 4 & 1.010 & - & Aditif & - \\
\hline conyzoides + serbuk & 5 & 0.770 & - & Sinergistik lemah & - \\
\hline \multirow[t]{5}{*}{ rimpang C. longa } & 6 & 0.609 & - & Sinergistik lemah & - \\
\hline & 7 & 0.599 & 0.588 & Sinergistik lemah & Sinergistik lemah \\
\hline & 8 & 0.641 & 0.674 & Sinergistik lemah & Sinergistik lemah \\
\hline & 9 & 0.614 & 0.576 & Sinergistik lemah & Sinergistik lemah \\
\hline & 10 & 0.661 & 0.625 & Sinergistik lemah & Sinergistik lemah \\
\hline
\end{tabular}

\section{KESIMPULAN DAN SARAN}

Campuran serbuk daun A. conyzoides dengan serbuk rimpang $C$. longa dan $Z$. officinale lebih beracun daripada serbuk tunggalnya dan bersifat sinergis terhadap imago $S$. oryzae. Campuran serbuk daun $A$. conyzoides dengan serbuk rimpang $Z$. officinale lebih beracun dan bersinergis dibandingkan campurannya dengan serbuk rimpang $C$. longa. Aplikasi serbuk daun A. conyzoides, serbuk rimpang C. longa dan Z. officinale secara tunggal dan campurannya dapat digunakan untuk mengendalikan hama $S$. oryzae pada gabah dan padi selama penyimpanan.

\section{DAFTAR PUSTAKA}

Ahmad, F., M. Sagheer, A. Hammad, S.M.M. Rahman, M. Ul-Hasan. 2013. Insecticidal activity of some plant extracts against Trogoderma granarium (E.). The Agriculturists. 11(1): 103-111.

Asawalam, E.F., U.E. Ebere, K.C. Emeasor. 2012. Effect of some plant products on the control of riceweevil Sitophilus oryzae (L.) Coleoptera: Curculionidae. Journal of Medicinal Plants Research. 6(33): 48114814.

Batta, Y.A. 2004. Control of rice weevil (Sitophilus oryzae L.) (Coleoptera: Curculionidae) with various 
formulations of Metarhizium anisopliae. Crop Protection. 23: 103-108.

Benhalima, H., M.Q. Chaudhry, K.A. Mills, N.R. Price. 2004. Phosphine resistance in stored-product insects collected from various grain storage facilities in Morocco. Journal of Stored Products Research. 40: 241-249.

Bouda, H., L.A. Tapondjoua, D.A. Fontemb, M.Y.D. Gumedzoe. 2001. Effect of essential oils from leaves of Ageratum conyzoides, Lantana camara and Chromolaena odorata on the mortality of Sitophilus zeamais (Coleoptera, Curculionidae). Journal of Stored Products Research. 37: 103-109.

Chander, H., D.K. Ahuja, A. Nagender, S.K. Berry. 2000. Repellency of different plant extracts and commercial formulations used as prophylactic sprays to protect bagged grain against Tribolium castaneum. Journal of Food Science and Technology. 37: 582-585.

Chayengia, B., P. Patgiri, Z. Rahman, S. Sarma. 2010. Efficacy of different plant products against Sitophilus oryzae (Linn.) (Coleoptera: Curculionidae) infestation on stored rice. Journal of Biopesticides. 3(3): 604-609.

Chou, T.C., P Talalay. 1984. Quantitative analysis of doseeffect relationships: the combined effects of multiple drugs or enzyme inhibitors. Advances in Enzyme Regulation. 22: 27-55.

Damalas, C.A. 2011. Potential uses of turmeric (Curcuma longa) products as alternative means of pest management in crop production. Plant Omics Journal. 4(3):136-141.

Franz, A.R., N. Knaak, L.M. Fiuza. 2011. Toxic effects of essential plant oils in adult Sitophilus oryzae (Linnaeus) (Coleoptera, Curculionidae). Revista Brasileira de Entomologia 55(1): 116-120.

Gani, S. 2010. Uji efektivitas tepung daun babadotan (Ageratum conyzoides L.) terhadap kumbang beras (Sitophilus oryzae L.) (Coleoptera: Curculionidae) di laboratorium. Mangaro. 1(1): 33-35.

Gisi, U. 1996. Synergistic interaction of fungicides in mixtures. Phytopathology. 86: 1273-1279.

Govindan, K., S.J. Nelson, S.J. 2009. Insecticidal activity of twenty plant powders on mortality, adult emergence of Sitophilus oryzae L. and grain weight loss in paddy. Journal of Biopesticides. 2(2): 169-172.

Hendrival \& Marwan. 2016. Aktivitas insektisida nabati terhadap mortalitas dan penghambatan kemunculan imago Sitophilus oryzae L. Jurnal Agrista. 20(2): 6374.

Iqbal, J., A. Qayyum, S.Z. Mustafa. 2010. Repellent effect of ethanol extracts of plant materials on Tribolium castaneum (Herbst) (Tenebrionidae: Coleoptera). Pakistan Journal of Zoology. 42: 81-86.

Li, R., C. Xiang, X. Zhang, D.A. Guo, M. Ye. 2010. Chemical analysis of the Chinese herbal medicine turmeric (Curcuma longa L.). Current Pharmaceutical Analysis. 6: 256-268.

Moreira, M.D., M.C. Picanço, L.C.A. Barbosa. 2007. Plant compounds insecticide activity against Coleoptera pests of stored products. Pesquisa Agropecuária Brasileira. 42(7): 909-915.

Nicholson, R.A., A. Zhang. 1995. Surangin B: Insecticidal properties and mechanism underlying its transmitter releasing action in nerve terminal fractions isolated from mammalian brain. Pesticide Biochemistry and Physiology. 53: 152-163.

Okunade, A.L. 2002. Ageratum conyzoides L. (Asteraceae). Fitoterapia. 73: 1-16.

Owolabi, M.S., M.O., Oladimeji, L. Lajide, G. Singh, P. Marimuthu, V.A. Isidorov. 2009. Bioactivity of three plant derived essential oils against the maize weevils Sitophilus zeamais (Motschulsky) and cowpea weevils Callosobruchus maculatus (Fabricius). Electronic Journal of Environmental Agriculture and Food Chemistry. 8: 828-835.

Park, I.K., S.G. Lee, D.H. Choib, J.D. Park, Y.J. Ahna. 2003. Insecticidal activities of constituents identified in the essential oil from leaves of Chamaecyparis obtusa against Callosobruchus chinensis (L.) and Sitophilus oryzae (L.). Journal of Stored Products Research. 39: 375-384.

Shaaya, E., M. Kostjukovski, J. Eilberg, C. Sukprakarn. 1997. Plant oils as fumigants and contact insecticides for the control of stored product insects. Journal of Stored Products Research. 33: 7-15.

Singh, S., P.J. Rao. 2000. Effect of Ageratum conyzoides on development and reproduction of Spodopera litura. Entomology. 102: 217-224.

Tavares, W.S., S.S. Freitas, G.H. Grazziotti, L.M.L. Parentec, L.M. Lião, J.C. Zanuncioe. 2013. Arturmerone from Curcuma longa (Zingiberaceae) rhizomes and effects on Sitophilus zeamais (Coleoptera: Curculionidae) and Spodoptera frugiperda (Lepidoptera: Noctuidae). Industrial Crops and Products. 46: 158-164. 
Ukeh, D.A. 2008. Bioactivities of essential oils of Afromomum melegueta and Zingiber officinale Both (Zingiberaceae) against Rhyzopertha dominica (Fabricius). Journal of Entomology. 5(3): 193-199.

Xiao, Y.C., J. Xie, M., Yu, J., Ran, Z., Xi, W. Li, J Huang, J. 2011. Bisabocurcumin, a new skeleton curcuminoid from the rhizomes of Curcuma longa L. Chinese Chemical Letters. 22: 1457-1460.

Zhang, J.S., J. Guan, F.Q. Yang, H.G. Liu, X.J. Cheng, S.P.
Li. 2008. Qualitative and quantitative analysis of four species of Curcuma rhizomes using twice development thin layer chromatography. Journal of Pharmaceutical and Biomedical Analysis. 48: 10241028.

Zheng, J., D. Leong, G. Lees, A. Nicholson. 1998. Studies on the interaction of surangin $B$ with insect mitochondria, insect synaptosomes, and rat cortical neurons in primary culture. Pesticide Biochemistry and Physiology. 61: 1-13. 